\title{
Passing The Buck, the Bane of Corporate Social Responsibility in Nigeria
}

Idowu A.

\begin{abstract}
Corporate Social Responsibility in Nigeria has gained recognition as obtained in the developed economies of the world as higher proportion of organizations, both local and multinational operating therein have grafted it in their business philosophies. However, the weak legal system and lack of advocacy by the concerned stakeholders have been relegating the actual performance to the background. The host communities of these organizations (safe the explorative organizations) have been in a state of uttermost negligence while the little real CSR initiatives have been concentrated in already developed areas of big cities and health initiatives outside the reach of the uneducated community members of these organizations who have been avoiding their responsibilities to local communities by passing same to the local, state and federal governments who are the original owners of most resources and infrastructures in such communities.
\end{abstract}

Index Terms - Corporate Social Responsibility, Bank, Organization, Stakeholders.

\section{INTRODUCTION}

Highlight As the world's population increases and technology becomes more advanced, the rate of innovation becomes as well more alarming, all in the bid to meet the demands of the growing world population. This advancement in all fronts did not leave out business organizations and Government institutions, the attendant impact been more pressure on the balance of nature.

The shifts and ever increasing pressure on the world's ecosystem is making the nations of the world to become more concern and proactive in putting in place measures to enhance its sustainability, this has been in the forms of legislations to various organizations and the embracement of environmentally sustainable business practices and moral advices to become more generally responsible in their practices, this is also in a bid to make their business profitability sustainable.

However, most of the laws are weak in that these organizations always finds loop holes as an excuse to go about any business policy with little regard to their environments, in developed nations where enforcement is high, these organizations seldom meets the minimum legal requirement of such laws, while in the developing nations, bribing their ways through with corrupt Government agencies has been the order of the day. Thanks to the creation of

Idowu A., Department of Management and Accounting Faculty of Management Sciences, Ladoke Akintola University of Technology, Ogbomoso. Oyo State. Nigeria.
Customer awareness, especially by non- profit oriented organizations on the need for these organizations to become more ethical in their modes of operations which has made more Customers to become more ethical conscious, hence influencing the policy of organizations even more than the legal framework could do.

This new drive by the Customers, who remains a pivotal stakeholder of any organization, has led to increasing corporate responsibility of these organizations. The reason for this could not be farfetched, without consumer's consumption, their production of either goods or services can never be sustainable.

Although, in the recent times, these organizations are finding an hiding nest in blame games or passing on of their expected responsibilities to the arms of government or in finding excuses for their acts of irresponsibility. This paper seeks to investigate how this bad habit is impairing Corporate Social Responsibilities (CSR) of organizations in Nigeria. It will also seek to shed more light on the community responsiveness of these organizations while possible measures to becoming more responsible will be proffered at the end.

\section{ORGANIZATION AND ITS STAKEHOLDERS}

An organization is an aggregation of individuals and resources towards the attainment of a concrete goal or objective(s). Generally, organizations are classified based on these two broad objectives, profit and philanthropy or not for profit (McNamara, 2018). The profit oriented organizations are broadly categorized as business organizations and in so doing, harnesses their resources towards the achievement of its primary objective, profit. The drive for more profits (as human wants are insatiable) is thus the sole propelling force of such organizations.

It should be noted that, every organization irrespective of its objective operates in a definite environment, as such, none is in vacuum. This environment is broadly divided into two, the internal and external environments. The two holds almost an equal sway in the attainment of the organizational corporate objectives. While the internal environment defines the aggregation of an organizations shareholders, employees and suppliers, the external environment comprises of the community the organization is, its customers, distributors and government (Friedman, 2006). The whole idea of organizational environment is primarily summed in its stakeholders. 


\section{ORGANIZATIONAL STAKEHOLDERS}

There had been innumerable attempts to simplify and set boundary between the concepts of stakeholders in the literatures with no general ground found for the definition. This shows the multidimensional approaches to the concept as various definitions are tailored to the objective or the context been discussed. However, traditionally, stakeholder is seen as any definite group or individuals who the attainment of an organization's objectives is capable of been affected or can affect it (Freeman, 1984). Interestingly, the passage of time has led to a re-conception of the idea even by the leader of thought in the area, stakeholder is now more recently viewed as individuals vital to the achievement of the organizational objectives. (Freeman, 2004). Every other views are coined from this foremost thought (Roberts and Mahoney, 2004).

The possibility of affecting or been affected by the achievement of organizational objectives sets a broader net on the concept of stakeholders, this is because of the ripple effects the processes of achieving such objectives leave behind, especially when the partners (suppliers and distributors) of an organization are involved. This also implies that, every recipient of the positive and negative externalities or byproducts of an organization's business activities are its stakeholders.

Consequently, this is posing a new challenge to organizations in the area of determination of its core and fringe stakeholders so adequate measures could be made to strike balance between them and relate with them in order of their importance to the organization (Parson, 2001). In ranking these stakeholders, the contributions of Mitchell, Agle and Wood (1997) is immense, they identified three major factors to be looked into for such ranking, the influence, legitimacy of the stakeholders claims as well as the urgency of the organization to meet such claims. The number of such factor met by any stakeholder defines its ranking, if one, the stakeholder is classified as been latent or low, two, moderate priority and if the three are perceived, then, highly ranked.

Urgency defines the time factor the organization have to attend to the claims or demand of the stakeholder, failure without which the stakeholder could result into actions that could undermine the achievement of the organizational objectives. It thus follows that, where minimum time is required, high urgency is the case, this ranks the stakeholder highest. The undoing of this classification is that, it does not cut across board for all the classes of the stakeholders as high urgency can only be accorded organized stakeholder with sustained pressing demand. Citing the oil rich Niger Delta region of Nigeria, the youth, representing the local community of multinational oil companies, had to organize themselves into formidable weapon bearing groups to have their claims accorded higher urgency. This is often elusive to the local community wherein banking halls are sited.

However, the dynamism and subjectivity of the possession of such criteria makes the classification more difficult. For instance, a shareholder may possess all these criteria in the morning but ripped of them all by evening if he had sold his shares, relocated or no longer enlist in the services of the organization, the reverse can also be the case. Subjectivity in the sense that, the attribution of some of those criteria to any stakeholder is also at the prerogative of the organization. This becomes more of a herculean task to the organization when there is no clear cut between the type and status of the stakeholder. For instance, a shareholder in an organization, who is also a Consumer, employee and resident of the local community of the organization(Freeman 2004).

Sadly, there have been a general perceived trend in the conceptualization of stakeholder by modern organizations in the developing world especially, this is based on the premise of their relationship or treatment of their stakeholders with uttermost reference to their local community. There seems to be a more concentration on their shareholders, customers and moderate concentration on their employees at the detriment of their local communities (Ijaiya, 2014), for instance, some banks operating in Nigeria posited that, the reason they are still in business is because of their shareholders and employees, this is anti-community and values the CSR stands for. The more reason the United Nations (UN) waded into the setting of environmentally operational standards for these set of organizations (United Nation, 1972). Also, in some organizations, the financial sector for instance, seems to perceive that they are not adding much pressure to the balance of ecosystem directly or to their immediate communities, hence are much more concentrated on their shareholders and customers.

\section{THE CONCEPT OF CORPORATE SOCIAL RESPONSIBILITY}

Corporate social responsibility CSR in the present-day business world have had its important contribution to the attainment of organizational goals, both economic and social goals, stressed, not only in the literatures but in the real business world, little wonder it has been engraved into the core policy formulation of any seriously minded business organization, for which reason it has also become a universal discus amongst the global world of academia (McWilliams et al, 2006). The concept is being make used off by way of complying with the legal requirement of various government's agencies both locally and internationally and has also become a veritable tool for appealing to the ethical sense of their customers, culminating in improved patronage cum profitability (Lee, 2008). The economic goal of an organization focuses majorly on achieving the expectations of its internal stakeholders, the shareholders and the employees by way of creating more values for their investment and social goal relates to the promotion of human rights, fair trade, legal compliance, environmental sustainability practices and cordial relationship with host communities. (Lee, 2008).

In the mid-19th century, the concept of CSR was viewed from the philanthropic perspective and was accordingly defined by Bowen (1953) as any attempt by an organization to pursue those policies and practices viewed by the general society has being greatly prized based on the values the society attaches to them. This definition suggests that, organizations are not to be solely influenced and controlled 
by only its internal objectives but should have the general society incorporated into its plans. It further suggests that, the value each society attaches events differs, hence organizations are to be dynamic in their approach with the peculiarities of their immediate environments at heart.

Drucker(1954) defined CSR as managerial initiatives that seeks to promote the creation of public goods, enhances societal values, stability and harmony. These and many other school of thought in this period have some common grounds, the advancement of societal interests or claims in the organizations operating within their domain. This is not to say that the society wanted the organizations to forget its profiteering primary objective, it only envisaged managers to strike balance between these objectives, and hence, the managers are more of public trustees or intermediaries between the organizations and their societies Frederick (2006).

The great industrial revolution that greeted the $21^{\text {st }}$ century coupled with increased environmental awareness of the world's populace and governments of the day sets another tune for the conceptualization and understanding of the CSR concept, and later moved from philanthropic dimension unto regulated practices. Thus, the leaders of thought this period sees CSR initiative of organizations as a reflex to institutional legal framework and a means of escaping the fierce hammers of law, instrument for efficient competition (Glan, 2006). The concept thus metamorphosed to covering areas as accountability, transparency, ethical competition, and ultimate inclusion or replacement of the world shareholders by, stakeholders (Waddock, 2008).

From the foregoing, it is evident that CSR does not have a consensus definition as the passage of time and events seems to affect the scholar's perception of what it means. However, general to most if not all of these definitions are some basics or features that cut across geographical and opinion divides, some of which are been voluntary, externalities internalizing, stakeholder inclusion, economic and social responsibility alignment, practices and values inclusive, and beyond philanthropy (Aminu, Harashid and Azlan, 2015).

\section{CSR UNDERLINING CHARACTERISTICS}

CSR is seen as been inclusive of all actions and policies of an organization that stems beyond the base level of legal requirement. That organizations have now moved away to include in their CSR initiatives far more than the minimal legal requirement like environmental sustainability practices, transparency, healthy competition and what a view to including community development actions and such practices that are not punishable by any legal framework if not included (Crane et al, 2008). Some critics of this concept, particularly the monetarist economists argued that the element of voluntarism is the undoing of profit maximization of organizations which is the sole object of shareholders, neglecting the ethical influences on the consumption pattern of the $21^{\text {st }}$ consumers (Aminuet al, 2015).

\section{Externalities Internalizing}

In the real world situation, there are some planned or unplanned for byproducts of production processes which are borne by the communities, these are termed externalities, and it can be positive or negative depending on their effects. This can have an un-foretold damaging impact on the brand image in the case of negative externalities, hence the CSR initiatives seeks to internalize such costs from the communities either by way of reduction or compensation(Husted \& Allen, 2006).

One of the means of doing this is by legal framework imposed sanctions or a more discretionary proactive approach like environmentally friendly practices, discontinued production of harmful products or provision of adequate information to assist an healthy choice by the populace. For instance, the tobacco production organizations have been compelled to provide a possible long term effect on the consumption of their products, the manufacturing world (foods and drugs) now provides life span of their products while the service industries provides terms and conditions of their services.

\section{Stakeholders Inclusiveness}

Prior to CSR's concept expansion, organizations are solely profit oriented and this they do by employing any strategy they fit could lead to the actualization of their profit objective to their shareholders. In their own world, only shareholders and stakeholders are relevant. But, the concept of CSR introduction seems to have changed such perspective as any organization deem to be floating CSR initiative must have incorporated the shareholders, employees, legal entities, suppliers, environment and their host community into their plans and ultimately balancing them (McWilliams and Siegel, 2001). This is more so because in the words of Bowen (1984), they need them to survive. CSR also entails a careful analysis and rating of such stakeholders based on the urgency and legality of their claims as well as the power of their influence on the organization (Husted \& Allen, 2006).

\section{Economic and Social Alignment}

That organizations need to make economic gains and impacts on their community does not exempt them from being socially responsible and vice-versa. Thus, CSR seeks to seek the balance between these two important elements by eliminating their conflicting tendencies. It is understood that, as much as all the stakeholders excluding the shareholders desires social responsiveness from the organizations, they are also on the lookout for these organizations to improve their economic prosperity. CSR therefore seeks to harness these claims together reasonably without one affecting the other. (Edmondson \&Carroll, 1999).

\section{Practices and Values Inclusion}

Since managers as seen as public trustees and broker between the organizations they represents and the communities they operates, the personal values and practices or norms of themselves and their communities respectively is expected to have impact on the CSR initiatives of their organizations. This is another area of influence of CSR as it seeks to underline the basic reasoning behind whatever CSR initiatives of the organizations (Lei, 2011).

\section{Beyond Philanthropy}

Although, the concept was in the time pass viewed as been solely philanthropic in nature in some quarters of the world wherein it revolves through the discretionary intuitive of the organization, it has in the present day shifted to becoming a 
legally required practice, making it an instrumental variable to the attainment of organizational objectives. Hence, the need for it to be encrypted into the organizations practices(Grayson \& Hodges, 2004).

\section{CORPORATE SOCIAL RESPONSIBILITY THEORETICAL PERSPECTIVES}

There had been incremental interest in the concept of CSR from the last century, although the last few decades witnessed a sporadic growth of interest, this has led to the concept becoming more complex and ambiguous (Gray et al, 1995). Theories are meant to give a firm direction to any discus and serves as reference point for its understanding and interpretation, however, since the concept of CSR does not have a universally agreed definition and perspective to it, it then follows that, divergent theories were postulated to shed light on it (Deegan \& Gordon, 1996).

\section{Classical Theory}

The perspective of classical economists is profit maximization, hence, pro shareholders forms a part of the highest critics of the concept. They opined that, CSR contradicts the primary objective of organizations by only contributing to the expenses but not to income of any organization. It thus argued that CSR should remain a voluntary and or discretionary subject to organizations (Friedman, 1962) and (Levitt, 1983).

Waddock\&Graves, (1997), while supporting the pro capitalist theory argued that organizations should be left to concentrate on economic gains for their shareholders, while government should undertake the responsibility of providing public and welfare goods. Also, (Aupperleet al, 1985) concluded on negative correlation between CSR and organizational financial performance, howbeit in the short run, this further stressed CSR as anti-shareholder concept. However, this relationship have been empirically proven to be positive in the long-run. (Margolis \& Walsh, 2003, Garriga and Mele, 2004; Carroll \&Shabana, 2010).

This theory thus passes the buck unto the government by stressing it responsible for promoting the welfare of its citizens hiding under the guise that, CSR is predatory and inimical to the survival of especially the small and medium enterprises (SMEs). It should be noted that, Nigeria operates majorly a capitalist system of economy, hence, CSR could not strive well in the country as most of business organizations focuses on their shareholders' satisfaction. This scenario worsen overabundance of labour, making the country a destination for cheap labour seeking organizations. The employees were not included in CSR of these organizations until they formed a formidable union and until the organizations realized the economic cost associated with low employee retention.

\section{Legitimacy Theory}

This theory according to Dowling \&Pfeffer (1975) holds when the value of an entity who is a subset of a universal entity conforms to the values of such universal entity, a situation which does not hold predisposes the subset to the full wrath of its universal entity. Thus, legitimacy theory summarizes such organizational value system in tandem with the beliefs and value system of its external environments (Suchman, 1995). This theory further explains that, an organization in an environment can only have a legitimate right of full existence therein only when it has related values, norms and beliefs with such environment. This brought to bear the foundational definition of CSR as engagement in such activities by alignment to the claims of such entities needed for the survival of an organization.

This theory is hinged on performance, communication and perception. The initiatives being performed or implemented by the organization needs to be adequately perceived by the environment has been a congruent of its values, norms and beliefs. In so doing, it has to explore communication CSR to bring to fore its initiatives (Mobus, 2005). This implies that, since communication is a call and response concept, it has to be two-way traffic between the organization and the host community. The organization has to fully understand what represents "value" to the community, attend to it as deemed adequate and then communicate the feedback to the community itself (Deegan 2000). In achieving this, organizations needs to be a citizen of its community and actively participate in its life. It is a general belief that, acceptability is duly accorded initiatives whose beneficiaries are part of the formulation process rather than what is just sold to them(Dijken, 2007).

However, in the Nigerian banking sector, this theory is only maximally applied to favour the shareholders through the instrumentality of Annual General Meetings (AGMs) and yearly financial reports, perhaps as a panacea to avoiding legal sanctioning by the regulatory bodies. Also, their advertisements are mainly addressed towards their existing and potential customers in terms of services they offer (Idowu, 2014). Where the communities are informed, only a fragment that are in choicest cities are informed, the ironing of which is that, these people are mostly too busy with their personal lives to notice.

\section{Agency Theory}

This theory views business managers as appointees of the shareholders to oversee the affairs of the organization by protecting it (shareholder's) interests. The managers are thus seen as the shareholder's agent and who have an obligation to report their activities to the shareholders at the time appointed, the reporting is to enable the shareholders scrutinize the activities of the managers (Salazar \& Husted, 2008). This theory thus focuses on the fact that, the managers will only undertake such activities belief to enhance the objectives of their principals, the shareholders in order for them to have a renewed contract. This can be a disservice to CSR if the principals are only mindful of short term gains.

\section{Stakeholders Theory}

This theory is rather an encompassing theory as it stems beyond the interest of the shareholders alone to include all the parties needed by an organization to achieve its objectives. This also includes both the human and non-human (environment) components (Starik, 1995). Jones (1999) further categorized stakeholders into primary and secondary, tagging those without which an organization will not survive as primary and those whose impact do not have a direct 
bearing on the survival of the organization as its secondary. For instance, the employees, suppliers, customers and government agencies all have a direct impact on the survival of the organization while the community might not.

This theory was further classified into three by Donaldson \& Preston(1995) to include descriptive, normative and instrumental classes. While descriptive as the name implies, defines stakeholder's communication pattern, the instrumental defines the responsiveness of performance to stakeholder's claims and normative deals with acceptable treatment of the stakeholders.

Organizations have various stakeholders who are in practice remains almost impossible to satisfy concurrently, thus CSR was criticized as been an excuse outlet to swindle the organizations by their managers as its aides lack of accountability (Jensen 2008). However, the empirical evidence for which organizations still involves in CSR is for stakeholder's satisfaction. Waddock and Graves, (1997) established an improvement in organizational performance as CSR initiatives are enhanced, thus, stakeholders satisfaction can be used as a proxy for measuring organizational performance.

\section{Instrumental Theory}

This theory is in concord with the Classical theory in the area of profit maximization for the shareholders, however, it incorporates CSR as a strategy to achieving this, pointing out that, CSR when efficiently implemented, boosts the brand's image, attracts best brains and enhances their retention, creates a peaceful working environment for it and hence improved customers acceptability of their products, this will culminate in improved revenue that will neutralize the cost of the CSR (Johnson, 2003, O'Riordan\&Fairbrass, 2005, Aminuet al, 2015, Idowu \&Ojo, 2016).

\section{Brief CSR drives of some selected Nigerian banks}

As with global organizational practices in the financial sector of the economy, Nigerian banks are not left out in the provision of corporate social responsibility to their stakeholders (Idowu, 2014). However, it was noticed that, the stakeholder conceptualization of some of the banks studied are skewed largely towards their employees and customers, and were centralized only in their corporate headquarters, Lagos State, and where scattered, perceived regional headquarters like Ibadan, Enugu, Calabar, Kaduna, Abuja were only covered. Sadly, these are seats of government which enjoys considerable allocation of national resources to improve their outlooks and economic status of their populace. This act starves local communities of operations of these banks of deserved attentions.

The Nigerian banks deliver CSR through internal and external approaches, internally majorly via corporate philanthropy and foundations while the external approach is majorly via partnerships with NGO's (Idowu, 2014). However, it is perceived that the areas of intervention (like creation of public goods) greatly needed in the country is been passed to the various governments and also, the inclusion of local communities of banks in their CSR is at the lowest level. These were particularly monitored from year 2015 to 2017 financial year. Good performing with wilder national coverage banks like First Bank of Nigeria Plc, Access Bank
Plc, Zenith Bank, United Bank for Africa UBA, and Guarantee Trust Bank GTB were examined.

\section{Access Bank Nigeria Plc}

In the financial year ending 2015, the bulk of the banks CSR initiatives was on employee, customers and environmental sustainability drives. This is evidenced in their employee trainings, next generation leaders and gender equity, water conservation and greenhouse gas emission initiatives with close to nothing given back to their communities of operations, safe in Lagos State alone where the renovation of Keke Primary School, Agege was done. Others includes putting kids back to school initiatives and economic empowerment of widows of Nigerian Police Officers who died in active service, scholarships provision to secondary school level for their wards, in total, 10 kids were taken back to school, 4 kids of deceased Police Officers and 8 Widows affected, all in Lagos. Cooking Gas Cylinders were also distributed to 100 local food vendors (Mama put) in Abuja metropolis (Access Bank, 2016).

Year 2016 also did not witness much improvement from the bank. Although, the bank launched its Solar powered Automated Tellers Machines ATM initiative to reduce its environmental pollution from carbon emission and noise pollution from the use of diesel powered generators, bulk of the initiatives were employees centered, like, training, games, health week and women empowerment, all for staffs. Series of initiatives were also put in place for customers as well. The only area it touched the lives of the community was through partnership with Non-Governmental Organization(NGO), to create awareness on human trafficking, woman abuse and addiction, and as usual, all took place in the porch areas of Lagos (Access Bank, 2017).

Year 2017 also followed suit in essentially the same manner from previous years with awareness creation on cervical cancer in collaboration with an NGO and screening of 91 women from Lagos and it's environ. Catch them young initiative, an Information Technology Employee Volunteering Group of the bank wherein its trains young students in IT basics. This drive saw them adopting Gbara Community High School, Lekki (also in Lagos metropolis), training 800 students, 40 teachers and supplying the school with IT gadgets. The highlight of their CSR was the graduation of their 327 all women participants in skill acquisition who had started for the past 3 years. The participants were said to be drawn from Lagos, Ibadan, Abuja, Calabar, Enugu and Kaduna (Access Bank, 2018).

\section{First Bank of Nigeria Plc}

The bank seems to have a robust community based CSR spread across the country, although it was silent on the locations of such initiatives. These borders on Education Endowment Programme, Hope Rising Initiatives, Future First, Youth Leadership and Development, Junior Achievement Nigeria, The First Bank Sustainability Center and Employee Giving and Volunteering. Each of these initiatives have a well spelt out programs for their actualization. The complaint handling of the customers had also greatly improved with all been resolved without having to get to the regulator, the Central Bank of Nigeria CBN (First Bank, 2018) 


\section{Zenith Bank Nigeria Plc}

Like almost every other banks operating in Nigeria, the bank has its own CSR initiatives covering five core areas the bank perceives as been very important, education, health, ICT/Youth empowerment, infrastructure and sports. Although, the youth empowerment initiative came last, which might have been born out of a burning pressure to attend to their host community, however, there was not concrete or visible evidence of doing so across board.

Under its educational CSR, the bank among other things donated an ultra-modern ICT center to the University of Nigeria, Nsukka, library and some learning aid materials to the special students of the hearing impaired school in Ondo State and also donated an ICT laboratory to Bamaina Academy Dutse, in Jigawa State. These activities tend to be more spread across the nation also, they still are not convincingly community based project, but are rather more of customer base.

In health, it makes conscious efforts at raising fund to fight cancer with the collaboration of some NGO and donated mobile cancer centers in Abuja, the Federal Capital Territory. It also donated a health care center to Iga-Idugaran community in Lagos Island, a community mostly inhabited by well to do people. Although, it is expected that the bank would have also assisted the primary health care centers in all the communities of its branches nationwide as this would have been more life touching at the grass root level.

In the area of sport, the bank is one of the sponsors of the National Football Federation NFF and the Nigerian Female Basketball league, and a number of sporting events, but all in Lagos State. The bank claims to support the youth that will in turn support their host communities but there was no much evidence to suggest that it was more than a mere goal. (Zenith Bank, 2018)

\section{Guarantee Trust Bank GTB}

GTB, one of the leading brands in Nigeria banking sector prides itself as one of the pioneer and pace setter in CSR initiative in the country and thus does provides more details about its feats in this regard. Its CSR is anchored on four pillars in year 2015, these are, education, community development, arts and environment, each gulping 57\%, 35\%, $7 \%$ and $2 \%$ of its CSR's budget respectively. The bank believes that, the reason it exists and grows in brand image is because of its host communities and its customers. This is a rather more community enthusiast approach.

In education, the bank started an initiative in the year 2004 called, adopt a school. This the brand spreads across the geo-political zones of the country, a more inclusive and representative approach than most of its competitors in the sector. Although, the school will have to be from a densely populated area, by this, it believes it will be able to touch the core poor communities. It has thus far (as at 2015) fully adopted 6 schools, each from the geo-political zones of the country, and partially adopted several others. Once a school is adopted, the bank upgrades its infrastructures, enhances the capacity of its teachers (through trainings) and studentsthrough scholarships provisions, coaching, and physical education and events.
It in the year 2015, it awarded scholarship to 20 students, indigents to Ogun State while 200 students of secondary schools in Ondo State were trained on financial proficiency, 2,500 students given study materials to prepare for external examinations, sponsored the sporting competitions of such adopted schools and also donated educational materials to close to 20 tertiary institutions. Successfully organized Principal's Football tournament in Ogun and Lagos States where more than 45 million Naira was given out in prizes. It thus looks as though Lagos and Ogun States are the most beneficiary of these initiatives.

In the area of community development in the year 2015, the bank supported Autism Spectrum Disorder ASD children where more than 200 children were treated in Lagos University Teaching Hospital LUTH, provided radio sponsored supports for parents of such children. Provided support for 47 young sickle cell patient from its staff Charity Initiative, donated more than 40 million Naira to support fight against Ebola on African soil, supported 42 physically challenged children to take part in Olympic and provided relief materials for Internally Displaced Person's Camps IDPs. Environmentally, it adopted three public places in Sokoto, Lagos and Kano for beautification, utilizing solar energy to power its ATMs, shutting down early and encouraging paperless operations. (GTB, 2015).

The years 2016 and 2017 went essentially as the year 2015 in terms of initiatives but with more resources committed to its CSR, more art professionals signed and more art works bought and displayed across its branches nationwide. Fashion weekend was however created to showcase more of African designers, introduction of food and drink fair to promote local food businesses (GTB, 2015).

Summarily, all the banks examined had in place CSR departments and initiatives believed to be the very needs of their stakeholders, however, while many were more customer and shareholders eccentric only a few were more community focused. It was also discovered that, greater percentage if not all of their CSR efforts are concentrated in Lagos State and the neighboring Ogun State. Also, non was said to be a member of the Community Development Association CDA of their local branch community, a platform for which it is expected that they could explore to become more community responsive (GTB, 2015).

\section{CONCLUSION}

The concept of CSR in global organization's setting has gained huge and sustainable acceptance with many hitherto indifference organizations toward employing it, partly due to legal requirement and to earn ethical approval of the teaming consumers. However, most of the laws backing CSR in developing world are lacking the government's political will for enforcement while when it is enforced, it is partly. This has been the hiding place for organizations as they only need to meet the legal minimum requirement, that is, if they do not hope to swerve their ways through via corrupt government officials or very porous system of governance.

In the Nigeria especially, the communities where most organizations are located are in a state of uttermost 
negligence, this is in spite of the negative externalities such communities bears the cost of. Where CSR is done, it is majorly either on the social media where often times, faceless individuals are said to be the beneficiaries or at the corporate headquarters communities of such organizations, despite such communities been in developed areas and enjoying government's supports at all levels. It is saddening that, instead of stopping to paying lip services to CSR and including their local communities, these organizations are viewing such interventions and initiatives as would benefit their local environment has been solely a responsibility of the government.

\section{REFERENCES}

[1] Access Bank (2016, 2017, 2018). Sustainability Report (Online),Available https://www.accessbankplc.com/AccessBankGroup/media/Documents /Sustainable\%20Reports/2016-Sustainability-Report.pdf Accessed, October 2nd, 2018)

[2] Aminu A. H;Harashid H, and Azlan, A.(2015). Corporate Social Responsibility: A Review on Definitions, Core Characteristics and Theoretical Perspectives: Mediterranean Journal of Social Sciences MCSER Publishing, Rome-Italy, Vol 6 No 4 July,ISSN 2039-2117 (online) ISSN 2039-9340 (print).

[3] Aupperle, K.E., Carroll, A.B. and Hatfield, J.D. (1985). An empirical examination of the relationship between corporate social responsibility andprofitability, Academy of Management Review, 28 (2) 446-463

[4] Bowen, H. (1953) Social Responsibilities of the Businessman, Harper, New York.

[5] Carroll, A.B., andShabana, K.M. (2010). The business case for corporate social responsibility: A review of concepts, research and practice,International journal of management reviews, 12 (1)85-105

[6] Carroll, A.B.(1979). A three dimensional conceptual model of corporate performance. Academy of Management Review, 4(4), 497-505.

[7] Carroll, A.B.(1991). The pyramid of corporate social responsibility: Toward the moral management of organizational stakeholders. Business Horizons, 39-48.

[8] Clay, J. (2005). Exploring the Links between International Business and Poverty Reduction: A Case Study of Unilever in Indonesia, by Oxfam GB, and Unilever, Oxford press

[9] Crane, A., and Matten, D. (2007). Business ethics, 2nd edition, Oxford University Press Inc., New York.

[10] Crane, A., Matten, D., and Spence, L. (2008). Corporate social responsibility: Readings and cases in a global context, 2nd edition, Routledge pp.3-26

[11] Deegan, C. (2000). Financial Accounting Theory, McGraw Hill Book Company, Sydney

[12] Dijken, F.V. (2007). Corporate Social Responsibility: Market regulation and the evidence, Managerial Law, 49(4)141-184

[13] Donaldson, T., and Preston, L.E. (1995). The stakeholder theory of corporation: Concepts, evidence and implications. The Academy ofManagement Review, 20(1) 65-91

[14] Dowling, J., and Pfeffer, J. (1975). Organizational Legitimacy: Societal Values and Organizational Behaviour, Pacific Sociological Review, 18(1)122-136

[15] Drucker, P.F. (1954). The Practice of Management, Collins, New York USA

[16] Edmondson, V.C. and Carroll, A.B. (1999). Giving Back: An Examination of the Philanthropic Motivations, Orientations and Activities of LargeBlack-Owned Businesses, Journal of Business Ethics, 19(2): 171-9

[17] First Bank of Nigeria Holdings Plc Sustainability Reports

[18] Frederick, W.C. (2006). Corporation, Be Good! The Story of Corporate Social Responsibility, Dogear Publishing, Indianapolis USA

[19] Freeman R (1984). Strategic Management: A Stakeholder Approach. Boston, MA: Pitman

[20] Freeman R, (2004) A Stakeholder's Theory of Modern Corporations, Ethical Theory and Business. 7th Edition.

[21] Freeman, R.E. (1984) Strategic Management: A stakeholder approach, Pitman, Boston.

[22] Friedman, A.L and S. Miles (2001). Developing a Stakeholder Theory, Journal of Management and Studies, 39/1 1:21.
[23] Friedman, M. (1962). Capitalism and Freedom. The University of Chicago Press, USA

[24] Galan, J.I. (2006). Corporate social responsibility and strategic management, Journal of Management Studies, 43(7)1629-41

[25] Garriga, E. and Mele, D. (2004). Corporate Social Responsibility Theories: Mapping the Territory, Journal of Business Ethics, 53, 51-71

[26] Gray, R., Kouhy, R. and Lavers, S. (1995). Corporate social and environmental reporting a review of the literature and a longitudinal study of UKdisclosure. Accounting, Auditing \& Accountability Journal, 8 (2), 47-77

[27] Grayson, D. and Hodges, A. (2004). Corporate social opportunity: seven steps to make corporate social responsibility work for your business. Sheffield: Greenleaf

[28] Guarantee Trust Bank Plc Corporate Social Responsibility Reports.

[29] Husted, B. W., and Allen, D.B. (2006). Corporate social responsibility in the multinational enterprise: strategic and institutional approaches. Journal of International Business Studies, 37(6): 838-849.

[30] Idowu, A. andOjo, O. (2016). Factors necessitating Commercial Banks and Manufacturing Firms' Involvement in Corporate Social Responsibility in Nigeria. Binus Business Review, 7(3), 281-287. http://dx.doi.org/10.21512/bbr.v7i3.1672

[31] Idowu, A. (2014). Corporate Social Responsibility in Nigerian Banking Industry: When will the Lip-Service Games End? Journal of Economics and Sustainable Development. ISSN 2222-1700 (print) ISSN 2222-2855. Vol 5 No 22.

[32] Ijaiya, H. (2014).Challenges of Corporate Social Responsibility in The Niger Delta Region of Nigeria, Afe Babalola University: Journal of Sustainable Development Law And Policy 3(1) 60-70

[33] Johnson, H.H. (2003). Does it pays to be good? Social responsibility and financial performance, Business Horizon, (Dec/Nov.), pp. 34-40

[34] Jones, M. T. (1999). The Institutional Determinants of Social Responsibility. Journal of Business Ethics, 20(2), 163-169

[35] Lee, M.P. (2008). A Review of the Theories of Corporate Social Responsibility: Its Evolutionary Path and the Road Ahead. Management Reviews. Vol 10, pp 53-73.

[36] Lei, W. (2011). Factors affecting perceptions of Corporate Social Responsibility implementation: an emphasis on values, an unpublished PhDthesis, University of Helsinki

[37] Levitt, T. (1983). The Globalization of Markets. Harvard Business Review, 61(3) 92- 102

[38] Margolis, J.D. and Walsh, J.P. (2003). Misery Loves Companies: Rethinking Social Initiatives by Business. Administrative Science Quarterly,48(2) 268-305

[39] McNamara, C. (2018). Two Basic Types of Organizations: For-Profit (Business) and Nonprofit. Accessed October 15th, 2018 from: managementhelp.org/organizations/types.htm

[40] McWilliams, A., and Siegel, D. (2001). Corporate social responsibility: a theory of the firm perspective, Academy of Management Review. Vol. 26(1117-127.

[41] McWilliams, A., Siegel, D., and Wright, P. (2006). Corporate social responsibility: strategic implications, Journal of Management Studies, 43(1) $1-18$

[42] Mele, D. (2008). Corporate Social Responsibility Theories, In A. Crane (eds.). The Oxford Handbook of Corporate Socia Responsibility,Oxford University Press

[43] Mitchell, R.K., Agle, B.R., and Wood, D.J. (1997). Toward a theory of stakeholder identification and salience: Defining the principle of who and whatreally counts. Academy of Management Review, 22(4), $853-887$

[44] Mobus, J.L. (2005) Mandatory environmental disclosure in a legitimacy theory context.Accounting, Auditing and Accountability Journal, 18,492-517

[45] O'Riordan, L. andFairbrass, J. (2005). Theories of Corporate Social Responsibility Availableat: https://pdfs.semanticscholar.org/b4fa/d78430c5052282dc739e466faf2 c48f6cf75.pdf Retrieved, Sept 25th, 2018.

[46] Parson, A., (2001). What Makes Relationship Important? An Analysis of the Buyers Perspective. Proceedings of Tenth Biennial World Marketing Congress: Academy of Marketing Science, Global Marketing Issues at the turn of the Millennium, Volume X.

[47] Starik, M. (1995). Should trees have managerial standing? Toward stakeholder status for non-human nature, Journal of Business Ethics, 14 (3) 207-217

[48] Suchman, M.C. (1995). Managing legitimacy: Strategic and institutional approaches. Academy of Management Review, 20 (3) $571-610$

[49] Thorne, L., Mahoney, L., and Manetti, G. (2014). Motivations for issuing standalone CSR reports: A survey of Canadian firms, Accounting, Auditing and Accountability Journal, 27(4), 686 - 714. 
Passing The Buck, the Bane of Corporate Social Responsibility in Nigeria

[50] United Nations (1972). United Nations Conference on the Human Environment (Stockholm Conference).

[51] Waddock, S. (2008). Building a new institutional infrastructure for corporate responsibility, Academy of Management Perspectives. $87-108$

[52] Waddock, S.A. and Graves, S.B. (1997).The corporate social performance-financial performance link. Strategic Management Journal, 18 (4), pp.303-31

[53] Zenith Bank Plc Sustainability Reports 